\title{
Pengaruh Pemberian Vitamin D terhadap Gambaran Foto Toraks Pasien Tuberkulosis Paru Beretnis Batak
}

\author{
Debby Mirani Lubis, ${ }^{1,3}$ Yahwardiah Siregar, ${ }^{1}$ Bintang Y.M. Sinaga, ${ }^{2}$ Seri Rayani Bangun ${ }^{4}$ \\ ${ }^{1}$ Progam Studi Ilmu Biomedik, ${ }^{2}$ Departemen Ilmu Penyakit Paru, \\ Fakultas Kedokteran, Universitas Sumatera Utara, \\ ${ }^{3}$ Departemen Fisiologi, Fakultas Kedokteran, Universitas Muhammadiyah Sumatera Utara, \\ ${ }^{4}$ STIKes St. Elisabeth, Medan
}

\begin{abstract}
Abstrak
Tuberkulosis (TB) adalah penyakit menular yang sampai sekarang masih menjadi masalah kesehatan dunia. Vitamin D dapat berperan melawan bakteri Mycobacterium tuberculosis melalui mekanisme cathelicidin intraseluler. Penelitian ini bertujuan mengetahui pengaruh pemberian vitamin D terhadap perbaikan foto toraks pada pasien TB paru beretnis Batak. Sebanyak 42 pasien yang memenuhi kriteria inklusi diambil dari beberapa puskesmas di Kota Medan dan Kabupaten Deli Serdang selama bulan Januari-Juni 2016. Penelitian ini adalah penelitian analitik dengan desain eksperimental murni tersamar tunggal (single-blind randomized controlled trial). Pasien dibagi secara acak menjadi kelompok vitamin D dan kelompok plasebo. Kelompok vitamin D diberikan tablet vitamin D oral 100.00o IU (2,5 mg) sebanyak 4 kali pemberian (minggu ke-O, 2, 4, 6). Kedua kelompok diperiksa kadar vitamin D dan foto toraks sebelum dan sesudah pengobatan selama 8 minggu. Hasil penelitian menunjukkan bahwa kelompok dengan pemberian vitamin D menunjukkan kenaikan kadar vitamin D secara signifikan $(p=0,00)$ dibanding dengan kelompok yang diberi plasebo $(0,26)$. Tidak ada perbedaan yang bermakna pada perbaikan foto toraks $(\mathrm{p}=0,06)$ antara kelompok vitamin $\mathrm{D}$ dan plasebo, tetapi jumlah subjek yang mengalami perbaikan foto zona paru pada kelompok vitamin D lebih banyak dibanding dengan kelompok plasebo (2:1). Simpulan, pemberian vitamin D tidak memengaruhi perbaikan foto toraks pada pasien TB paru beretnis Batak.
\end{abstract}

Kata kunci: Foto toraks, suku Batak, tuberkulosis, vitamin D

\section{The Effect of Vitamin D on Chest X-ray Profile in Batak Ethnicity Pulmonary Tuberculosis Patients}

\begin{abstract}
Tuberculosis is an infectious disease that is still a global health problem. Vitamin D may play a role in fighting the bacteria Mycobacterium tuberculosis through the mechanism of intracellular cathelicidin. This study aimed to determine the effect of vitamin D on the improvement of chest x-ray in patients with pulmonary tuberculosis from Batak ethnicity. As much as 42 patients who met the inclusion criteria taken from several clinics in Medan City and Deli Serdang District in January to June 2016. This is a analytical study using single-blind randomized controlled trial design. Patients were divided into groups of vitamin $\mathrm{D}$ and placebo groups. Vitamin $\mathrm{D}$ group was given vitamin D tablet 100,00o IU ( $2.5 \mathrm{mg}$ ) orally 4 times (o, 2, 4, 6 weeks). Levels of vitamin D and chest x-ray before and after 8 weeks of treatment were examined. The results showed that group with vitamin D levels increased significantly $(\mathrm{p}=0.00)$ compared to the placebo group (0.26). There was no significant difference in the improvement of thoracic images $(\mathrm{p}=0.06)$ between group with vitamin $\mathrm{D}$ and placebo groups. However, the number of subjects who experienced improvement of lung zone images in the vitamin D group more than the placebo group (2:1). In conclusion, vitamin D does not affect the improvement of chest $\mathrm{x}$-ray in patients with pulmonary tuberculosis from Batak ethnicity.
\end{abstract}

Key words: Batak ethnicity, thorax photo, pulmonary tuberculosis, vitamin D

Korespondensi: Debby Mirani Lubis. Departemen Fisiologi, Fakultas Kedokteran, Universitas Muhammadiyah Sumatera Utara. E-mail: debbymiranilubis@yahoo.com 


\section{Pendahuluan}

Tuberkulosis (TB) adalah salah satu penyakit menular yang masih menjadi masalah kesehatan dunia sampai saat ini. Pada tahun 2013 menurut World Health Organization (WHO) diperkirakan terdapat 9 juta orang di seluruh dunia menderita TB (56\% kasus terdapat di wilayah Asia Tenggara dan Pasifik Barat) dan 1,5 juta kematian yang disebabkan oleh TB. Pada tahun 2013 Indonesia berada pada urutan ke- 5 estimasi insidensi kasus TB di seluruh dunia. ${ }^{1}$ Prevalensi TB berdasar atas pemeriksaan dahak, foto toraks, atau keduanya pada penduduk Indonesia sebesar 0,4\% (tahun 2013). ${ }^{2}$

Penelitian yang telah dilakukan sebelumnya menunjukkan bagaimana mekanisme vitamin D dalam meningkatkan daya tahan tubuh melawan infeksi bakteri M. tuberculosis. Vitamin D dapat meningkatkan sintesis dari komponen sistem imun bawaan melalui kompleks reseptor vitamin D (RVD) dengan bentuk aktif dari vitamin D, yaitu $1,25 \mathrm{D} 3$; salah satunya cathelicidin yang mempunyai peranan penting melawan infeksi Mycobacterium. Hal inilah yang dapat dijadikan dasar pemikiran melakukan penelitian pengaruh pemberian vitamin $\mathrm{D}$ terhadap perbaikan foto toraks pada pasien TB beretnis Batak. ${ }^{3}$

\section{Metode}

Penelitian ini adalah penelitian analitik dengan desain eksperimental murni tersamar tunggal atau single-blind randomized controlled trial. Pemilihan sampel penelitian ini menggunakan teknik consecutive sampling dengan kriteria inklusi, yaitu pasien TB paru BTA (+) kategori 1, laki-laki atau perempuan etnis Batak berusia 18-65 tahun. Etnis Batak diperoleh dari dua generasi sebelumnya (kakek-nenek, ayah-ibu). Kriteria eksklusi: terdapat defisiensi kekebalan seperti HIV, riwayat diabetes melitus, riwayat transplantasi organ, terdapat gangguan fungsi ginjal, terdapat gangguan fungsi hati, keganasan, pengobatan dengan steroid, hamil dan menyusui, penderita TB ekstraparu, alergi terhadap vitamin $\mathrm{D}$, pasien sedang dalam mengonsumsi vitamin $\mathrm{D}$, dan indeks massa tubuh $\leq 18,5$. Pengambilan sampel dilakukan di beberapa puskesmas di Kota Medan. Jumlah keseluruhan sampel sebanyak 42 penderita TB paru BTA (+) kategori 1 (kasus baru dan belum pernah mendapatkan pengobatan TB) serta beretnis Batak. Dari 42 sampel, sebanyak 21 orang masuk dalam kelompok vitamin $\mathrm{D}$ dan
21 orang masuk ke dalam kelompok plasebo. Pemeriksaan foto dada dilaksanakan oleh dokter spesialis radiologi yang sedang bertugas di tempat pengambilan foto. Pemeriksaan kadar vitamin D dilakukan dengan teknik ELISA di Laboratorium Terpadu FK USU.

Variabel bebas adalah pengaruh pemberian vitamin D pada pasien TB paru beretnis Batak dan variabel terikatnya adalah perbaikan foto toraks. Karakteristik subjek berdasar atas jenis kelamin, usia, dan tempat pengambilan sampel merupakan tabel frekuensi. Data yang diperoleh dicatat dan ditabulasi serta diolah secara statistik menggunakan program SPSS. Untuk mengetahui perubahan kadar vitamin $\mathrm{D}$ itu sebelum dengan sesudah perlakuan dilakukan uji T-berpasangan apabila data berdistribusi normal, bila tidak normal dilakukan uji nonparametrik Wilcoxon. Untuk menilai hubungan pemberian vitamin D dengan perbaikan foto toraks digunakan uji chisquare.

\section{Hasil}

Subjek penelitian berjumlah 42 orang terdiri atas 27 laki-laki dan 15 perempuan. Pada kelompok vitamin D kelompok usia paling banyak adalah kelompok termuda 7 dari 21 orang (19-25 tahun), sedangkan pada kelompok plasebo paling banyak pada kelompok 41-47 tahun, yaitu 8 dari 21 orang. Berdasar atas riwayat kebiasaan merokok, kelompok vitamin D dan plasebo memiliki jumlah subjek yang sama, yaitu 11 dari 21 orang merokok masing-masing.

\section{Tabel 1 Distribusi Karakteristik Subjek Penelitian}

\begin{tabular}{cccc}
\hline Variabel & $\begin{array}{c}\text { Vitamin D } \\
\mathbf{n = 2 1}\end{array}$ & $\begin{array}{c}\text { Plasebo } \\
\mathbf{n = 2 1}\end{array}$ & $\begin{array}{c}\text { Total } \\
\mathbf{n = 4 2}\end{array}$ \\
\hline Jenis kelamin & & & \\
Laki-laki & 14 & 13 & 27 \\
Perempuan & 7 & 8 & 15 \\
Usia (tahun) & & & \\
19-25 & 7 & 1 & 8 \\
26-33 & 4 & 0 & 4 \\
$34-40$ & 3 & 0 & 3 \\
$41-47$ & 6 & 8 & 14 \\
$48-54$ & 0 & 6 & 6 \\
55-61 & 0 & 5 & 5 \\
62-63 & 1 & 1 & 2 \\
Riwayat merokok & & & \\
Ya & 11 & 11 & 22 \\
Tidak & 10 & 10 & 20 \\
\hline
\end{tabular}


Tabel 2 Kadar Vitamin D Rata-rata Subjek Penelitian Sebelum dan Sesudah Pengobatan pada Kedua Kelompok

\begin{tabular}{lccccc}
\hline Kelompok & $\mathbf{n}$ & $\begin{array}{c}\text { Mean } \pm \text { SD } \\
\text { Sebelum }\end{array}$ & $\begin{array}{c}\text { Mean } \pm \text { SD } \\
\text { Sesudah }\end{array}$ & $\begin{array}{c}\text { Perbedaan } \\
\text { Rata-rata }\end{array}$ & Nilai p \\
\hline Vitamin D & 21 & $30,93 \pm 8,78$ & $60,62 \pm 21,24$ & $29,69 \pm 21,42$ & 0,00 \\
Plasebo & 21 & $29,81 \pm 7,54$ & $31,21 \pm 8,18$ & $1,39 \pm 5,49$ & 0,26 \\
\hline
\end{tabular}

Tabel 3 Distribusi Frekuensi berdasarkan Luas Lesi Foto Toraks Sebelum Pengobatan pada Kedua Kelompok

\begin{tabular}{lccc}
\hline \multirow{2}{*}{ Luas Lesi } & Vitamin D & Plasebo & Total \\
\cline { 2 - 4 } & $\mathbf{n = 2 1}$ & $\mathbf{n = 2 1}$ & $\mathbf{n = 4 2}$ \\
\hline Minimal & 0 & 1 & 1 \\
Moderat & 11 & 11 & 22 \\
Far advance & 10 & 9 & 19 \\
\hline
\end{tabular}

Perbedaan kadar vitamin D rata-rata sebelum dibandingkan dengan sesudah pengobatan pada kelompok vitamin D: $29,69 \mathrm{ng} / \mathrm{mL}(\mathrm{SD}=21,42)$, sedangkan kelompok plasebo sebesar $1,39 \mathrm{ng} /$ $\mathrm{mL}(\mathrm{SD}=5,49)$. Pada uji t-berpasangan didapat $\mathrm{p}=0$,oo pada kelompok vitamin D yang berarti ada kenaikan bermakna kadar vitamin D ratarata sebelum dengan sesudah pengobatan. Pada uji yang sama untuk kelompok plasebo $\mathrm{p}=0,26$ yang berarti tidak ada kenaikan yang bermakna kadar vitamin D rata-rata sebelum dibandingkan dengan sesudah pengobatan.

Penilaian foto toraks pada penelitian ini terdiri atas penilaian luas lesi, perbaikan luas lesi, serta jumlah zona yang menunjukkan kerusakan dan perbaikan pada foto toraks.

Menurut American Tuberculosis Association, ${ }^{4}$ foto toraks dapat dikategorikan menjadi empat kategori berdasar atas luasnya lesi, yaitu negatif, minimal, moderat, dan far advance. Tidak ada subjek yang memiliki luas lesi minimal pada kelompok vitamin D dan terdapat seorang yang mempunyai luas lesi minimal pada kelompok plasebo. Luas lesi yang paling banyak dijumpai pada subjek penelitian adalah luas lesi moderat. Berdasarkan atas perubahan luas lesinya sesudah pengobatan, dijumpai lima kategori perubahan seluruh subjek penelitian, yaitu perubahan dari moderat menjadi minimal, far advance menjadi moderat, far advance menjadi minimal, kategori far advance menjadi negatif, dan kategori subjek yang tidak mengalami perubahan yang bermakna pada luasnya lesi. Dalam penelitian ini, kategori tidak terdapat perubahan pada foto toraks berarti tidak ada perubahan kategori luas lesi meskipun terdapat pengurangan kepadatan pada area yang mengalami kerusakan.

Pada foto toraks, paru dapat dibagi menjadi enam zona (lapangan paru), yaitu zona kanan atas, kiri atas, kanan tengah, kiri tengah, kanan bawah, dan kiri bawah yang dipisahkan oleh iga (costa) kedua dan keempat anterior. Penilaian

Tabel 4 Distribusi Frekuensi berdasarkan Perubahan Luas Lesi Foto Toraks Sesudah Pengobatan pada Kedua Kelompok

\begin{tabular}{lccc}
\hline \multirow{2}{*}{ Perubahan Luas Lesi } & Vitamin D & Plasebo & Total \\
\cline { 2 - 4 } & $\mathbf{n}=\mathbf{2 1}$ & $\mathbf{n = 2 1}$ & $\mathbf{n = 4 2}$ \\
\hline Tidak ada perubahan & 8 & 15 & 23 \\
Moderat $->$ minimal & 7 & 1 & 8 \\
Far advance $-->$ moderat & 5 & 4 & 9 \\
Far advance $-->$ minimal & 1 & 0 & 1 \\
Far advance $-->$ negatif & 0 & 1 & 1 \\
\hline
\end{tabular}


Tabel 5 Perbedaan Jumlah Perbaikan Zona Foto Toraks pada Kedua Kelompok

\begin{tabular}{ccc}
\hline \multirow{2}{*}{ Jumlah Perbaikan Zona } & Vitamin D & Plasebo \\
\cline { 2 - 3 } & $\mathbf{n = 2 1}$ & $\mathbf{n = 2 1}$ \\
\hline 0 & 7 & 14 \\
1 & 10 & 3 \\
2 & 4 & 3 \\
3 & 0 & 1 \\
\hline
\end{tabular}

Tabel 6 Proporsi Perbaikan Zona Foto Toraks pada Kedua Kelompok

\begin{tabular}{cccc}
\hline \multirow{2}{*}{ Perbaikan } & Vitamin D & Plasebo & \multirow{2}{*}{ Nilai p } \\
\cline { 2 - 3 } & $\mathbf{n = 2 1}$ & $\mathbf{n = 2 1}$ & 0,06 \\
Menetap & 7 & 14 & \\
Membaik & 14 & 7 & \multirow{2}{*}{} \\
\hline
\end{tabular}

perbaikan pada zona paru di dalam penelitian ini adalah didapatkan zona yang bersih pada foto toraks setelah 2 (dua) bulan pengobatan. Pengurangan kepadatan pada zona yang rusak tidak masuk dalam kategori perbaikan. Pada penelitian ini dijumpai empat kategori perbaikan zona dari keseluruhan sampel, yaitu tidak ada perbaikan (o), perbaikan pada 1 zona, perbaikan pada 2 zona, dan perbaikan pada 3 zona. Tidak ada subjek penelitian yang mengalami perbaikan sejumlah 4, 5, dan 6 zona.

Pemberian vitamin D memperlihatkan jumlah perbaikan yang lebih banyak daripada plasebo, yaitu 14 orang dibanding dengan 7 orang. Uji chisquare menunjukkan $\mathrm{p}=0,06$ yang berarti tidak ada hubungan yang bermakna antara pemberian vitamin $\mathrm{D}$ dan perbaikan foto toraks pada pasien TB paru beretnis Batak.

\section{Pembahasan}

Karakteristik subjek penelitian dinilai berdasar atas jenis kelamin, usia, dan juga status merokok. Jenis kelamin yang banyak pada subjek adalah laki-laki (rasio=9:5). Keadaan ini sesuai dengan data WHO tahun 2014 bahwa jumlah kasus terbanyak penyakit tuberkulosis adalah laki-laki apabila dibanding dengan perempuan. Berdasar atas karakteristik usia, kelompok vitamin D mempunyai subjek terbanyak dengan rentang usia yang lebih muda (19-25 tahun) dibanding dengan kelompok plasebo (41-47 tahun). ${ }^{1}$ Hal ini berbeda dengan hasil Riskesdas tahun 2013 yang menyatakan prevalensi kasus TB meningkat dengan pertambahan usia. ${ }^{2}$ Berdasarkan riwayat kebiasaan merokok, kelompok vitamin $\mathrm{D}$ dan plasebo mempunyai jumlah subjek yang sama. Merokok merupakan salah satu faktor yang dapat memengaruhi imunitas. 5 Pada penelitian ini, dijumpai proporsi yang relatif sama antara subjek yang merokok dan tidak sehingga tidak dapat dikatakan bahwa merokok dapat memengaruhi kerentanan terhadap TB pada penelitian ini.

Pada kelompok vitamin D, status vitamin D sebelum pengobatan proporsi terbanyak adalah subjek dengan status vitamin D yang optimal yang sama halnya dengan kelompok plasebo. Hal ini sama dengan penelitian kasus kontrol yang dilakukan oleh Grange dkk. ${ }^{6}$ di Indonesia bahwa kadar vitamin $\mathrm{D}$ pada kasus $(\mathrm{n}=40)$ dan pada kontrol $(n=38)$ menunjukkan level yang optimal. Begitu juga dengan penelitian yang dilakukan Chan dkk. ${ }^{7}$ di Hong Kong maupun Davies dkk. di Thailand ${ }^{8}$ dan Kenya ${ }^{9}$ yang menunjukkan bahwa kadar vitamin D yang optimal pada kelompok kasus. Hasil yang berbeda pada penelitian yang dilakukan oleh Siswanto dkk. ${ }^{10}$ di Indonesia yang menunjukkan kadar vitamin D pasien TB berada dalam status defisiensi $(<20 \mathrm{ng} / \mathrm{mL})$. Hasil yang berbeda ini kemungkinan dapat dipengaruhi oleh berbagai hal salah satunya faktor etnis. Beberapa penelitian sebelumnya menunjukkan hasil yang berbeda pada populasi etnis yang berbeda.

Kenaikan kadar vitamin D yang bermakna didapatkan pada kelompok yang diberi vitamin $\mathrm{D}(\mathrm{p}=\mathrm{O}, \mathrm{oo})$ apabila dibanding dengan kelompok plasebo $(p=0,26)$. Hal ini kemungkinan dapat dipengaruhi oleh banyak hal antara lain dosis 
vitamin D yang cukup efektif, metode pemberian obat yang dilakukan (subjek mengonsumsi obat langsung di hadapan peneliti), ataupun fungsi penyerapan saluran cerna pasien dalam kondisi optimal yang kemungkinan berhubungan dengan indeks massa tubuh pasien yang normal.

Berdasar atas luas lesi pada foto toraks, subjek penelitian paling banyak memiliki lesi moderat. Hal ini sesuai dengan penelitian yang dilakukan oleh Salahuddin dkk. ${ }^{12}$ di Arab Saudi. Hal yang menarik didapatkan pada penelitian ini, yaitu delapan subjek yang tidak mengalami perubahan luas lesi pada kelompok vitamin D dan terdapat seorang pada kelompok plasebo yang mengalami perubahan foto luas lesi far advance menjadi negatif. Hal ini menunjukkan bahwa pengobatan tuberkulosis itu dapat dipengaruhi oleh banyak faktor selain imunitas, seperti virulensi kuman, kepatuhan pasien untuk meminum obat TB, dan etnisitas.

Pada penelitian ini pemberian vitamin D memperlihatkan bahwa jumlah perbaikan foto toraksyang lebih banyak daripada plasebo, namun uji statistik chi-square mempunyai nilai $\mathrm{p}=0,06$ yang berarti tidak ada hubungan yang bermakna antara pemberian vitamin D dan perbaikan foto toraks. Penelitian Siswanto dkk. ${ }^{10}$ menunjukkan perbedaan proporsi yang bermakna pada foto toraks antara kelompok vitamin D dan plasebo sesudah dilaksanakan 1 (satu) bulan pengobatan, namun sesudah dua bulan pengobatan perbedaan foto toraks itu menjadi tidak bermakna antara kedua kelompok. Penelitian yang dilakukan oleh Martineu dkk. ${ }^{13}$ juga memperlihatkan hasil tidak ada perbedaan bermakna pada zona yang terlihat pada foto toraks. Wejse dkk. ${ }^{14}$ memperlihatkan pemberian vitamin D (dosis 100.00o IU dua kali pemberian) tidak memengaruhi perbaikan klinis pada pasien. Keadaan yang berbeda dijumpai pada penelitian Salahuddin dkk. ${ }^{12}$ di Arab Saudi yang menunjukkan perbedaan bermakna jumlah zona rata-rata yang terlihat antara kelompok vitamin D dan kelompok plasebo. Di samping itu, terjadi perbedaan pengurangan ukuran kavitas yang bermakna antara kedua kelompok tersebut. Perbedaan hasil ini dapat disebabkan oleh banyak hal selain status imunitas pasien, yaitu virulensi kuman dan etnisitas seperti yang dikemukakan oleh Sutaria dkk. ${ }^{3}$

Proses penyembuhan penyakit tuberkulosis dapat dipengaruhi oleh banyak faktor selain kadar vitamin $\mathrm{D}$, di antaranya faktor imunitas, virulensi kuman (TB-MDR), serta faktor kebiasaan seperti merokok dan minum alkohol. Faktor etnis juga dapat memengaruhi kerentanan dan perbaikan terhadap tuberkulosis sehingga perlu dilakukan penelitian yang sama pada etnis yang berbeda dari penelitian ini.

Terdapat 7 (tujuh) orang pada kelompok D penelitian ini yang tidak mengalami perbaikan sedikitpun sesudah mendapat pengobatan TB. Untuk kasus seperti ini kemungkinan disebabkan oleh TB-MDR sehingga pada kasus ini seharusnya diperiksa gene expert untuk memastikannya.

\section{Simpulan}

Pemberian vitamin D pada TB paru beretnis Batak dengan dosis 2,5 mg (100.00o IU) sebanyak 4 kali (minggu ke-o, 2, 4, 6) meningkatkan kadar vitamin $\mathrm{D}$, namun tidak memengaruhi perbaikan foto toraks.

\section{Daftar Pustaka}

1. WHO. Global tuberculosis report 2014. Geneva, Switzerland: WHO Press; 2014.

2. Badan Penelitian dan Pengembangan Kesehatan, Kementerian Kesehatan RI. Riset kesehatan dasar (Riskesdas) 2013. Jakarta: Kemenkes RI; 2013.

3. Sutaria N, Liu CT, Chen TC. Vitamin D status, receptor gene polymorphisms, and supplementation on tuberculosis: a systematic review of case-control studies and randomized controlled trials. J Clin Transl Endocrinol. 2014;1(4):151-60.

4. Soetikno RD, Derry. Kesesuaian antara foto toraks dan mikroskopis sputum pada evaluasi respons pengobatan tuberkulosis paru setelah enam bulan pengobatan. MKB. 2011;43(3);140-5.

5. Sinaga BYM, Amin M, Siregar Y, Sarumpaet SM. Correlation between vitamin D receptor gene FOKI and BSMI polymorphisms and the susceptibility to pulmonary tuberculosis in an Indonesian Batak-ethnic population. Acta Med Indones. 2014;46(4):275-82.

6. Grange JM, Davies PD, Brown RC, Woodhead JS, Kardjito T. A study of vitamin D levels in Indonesian patients with untreated pulmonary tuberculosis. Tubercle. 1985; 66(3):187-91.

7. Chan TY, Poon P, Pang J, Swaminathan R, Chan $\mathrm{CH}$, Nisar M, dkk. A study of calcium and vitamin $\mathrm{D}$ metabolism in Chinese 
patients with pulmonary tuberculosis. J Trop Med Hyg. 1994;97(1):26-30.

8. Davies PD, Church HA, Bovornkitti S, Charumilind A, Byrachandra S. Altered vitamin D homeostasis in tuberculosis. Int Med Thailand. 1988;4:45-7.

9. Davies PD, Church HA, Brown RC, Woodhead JS. Raised serum calcium in tuberculosis patients in Africa. Eur J Respir Dis. 1987;71(5):341-4.

10. Siswanto, Sumarno, Jane Y, Widayanti OA, Muktiati NS. Pengobatan suportif vitamin D mempercepat konversi sputum dan perbaikan gambaran radiologis penderita tuberkulosis. JKB. 2009;25(3):128-32.

11. Rashedi J, Asgharzadeh M, Moaddab SR, Sahebi L, Khalili M, Mazani M, dkk. Vitamin $\mathrm{D}$ receptor gene polymorphism and vitamin D plasma concentration: correlation with susceptibility to tuberculosis. Adv Pharm Bull. 2014;4(Suppl 2):607-11.

12. Salahuddin N, Ali F, Hasan Z, Rao N, Aqeel
M, Mahmood F. Vitamin D accelerates clinical recovery from tuberculosis: results of the SUCCINCT Study [Supplementary Cholecalciferol in recovery from tuberculosis]. A randomized, placebo-controlled, clinical trial of vitamin D supplementation in patients with pulmonary tuberculosis. BMC Infect Dis. 2013;13:22.

13. Martineau AR, Timms PM, Bothamley GH, Hanifa Y, Islam K, Claxton AP, dkk. Highdose vitamin D3 during intensive-phase antimicrobial treatment of pulmonary tuberculosis: a double-blind randomised controlled trial. Lancet. 2011;377(9761):24250 .

14. Wejse C, Gomes VF, Rabna P, Gustafson $\mathrm{P}$, Aaby $\mathrm{P}$, Lisse IM, dkk. Vitamin $\mathrm{D}$ as supplementary treatment for tuberculosis: a double-blind, randomized, placebocontrolled trial. Am J Respir Crit Care Med. 2009;179(9):843-50. 